\title{
Goblet cell carcinoid of the appendix detected from a metastatic ovarian tumor
}

Rieko Kawase $^{1}$ and Shunji Suzuki ${ }^{1}$

${ }^{1}$ Nippon Medical School

June 13, 2021

\section{Abstract}

Goblet cell carcinoid is usually diagnosed after simple appendectomy; however, the current case was detected from a metastatic ovarian tumor.

\section{Hosted file}

GCC Kawase (CCR).doc available at https://authorea.com/users/419576/articles/526034-gobletcell-carcinoid-of-the-appendix-detected-from-a-metastatic-ovarian-tumor

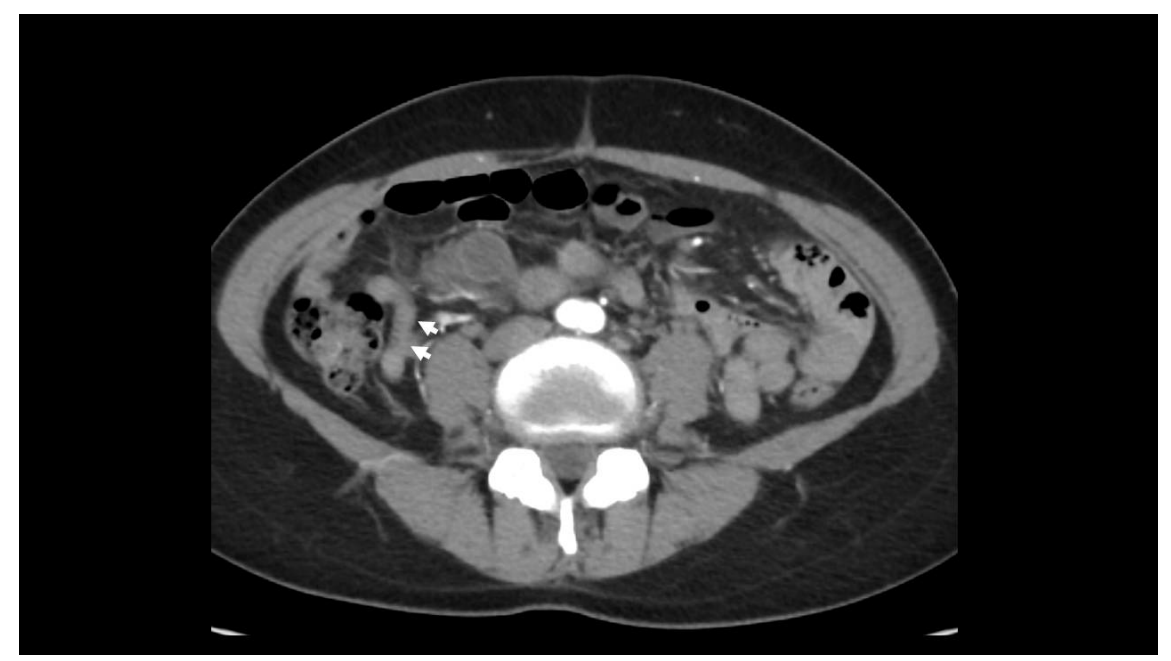

